\title{
СУЧАСНІ ПІДХОДИ ДО ФОРМУВАННЯ ПРОФЕСІЙНИХ КОМПЕТЕНТНОСТЕЙ
} ПРИ ОРГАНІЗАЦІЇ ТА ПРОВЕДЕННІ ПРАКТИЧНИХ ЗАНЯТЬ ІЗ ФІЛОСОФІЇ

\section{MODERN APPROACHES TO THE FORMATION OF PROFESSIONAL COMPETENCIES IN ORGANIZING AND CONDUCTING PRACTICAL CLASSES ON PHILOSOPHY}

УДК 371.013

DOI https://doi.org/10.32843/2663-

$6085 / 2021 / 34-2.26$

\author{
Фуркало В.С., \\ канд. фрілос. наук, \\ доцент кафедри соціальних \\ і правових дисциплін \\ Уманського державного педагогічного \\ університету імені Павла Тичини \\ Фуркало В.І., \\ канд. фрілос. наук, \\ доцент кафедри соціальних \\ і правових дисциплін \\ Уманського державного педагогічного \\ університету імені Павла Тичини
}

\begin{abstract}
Система фрормування професійної компетентності майбутнього фрахівця в закладах вищої освіти історично передбачала детальне вивчення фрілософрії. Профресійна компетентність майбутнього спеціаліста включає здатність до виявлення найбільш загальних закономірностей розвитку світу, виражених у принципах, законах, категоріях; вивчення сучасного й минулого, можливого майбутнього, що водночас $i$ становить наукове завдання фрілософії. $У$ статті розглянуто сучасні підходи до формування професійних компетентностей під час організації та проведення практичних занять із фрілософрії. Філософрія в закладах вищої освіти є важливою навчальною дисципліною, яка фрормує у майбутнього спеціаліста цілісну картину світу, реалізує здатність надавати визначення процесам та явищам, розвиває вміння формулювати, впорядковувати, послідовно викладати свою позицію. Професійна компетентність характеризується як багатоаспектне утворення і включає фрундаментальну, предметну, психолого-педагогічну, методичну компетентності. Визначено, що вивчення фрілософії студентами збагачує їх науковими знаннями світоглядного характеру та допомагає в профресійній діяльності, перестає бути спрямованим лише на розвиток загальної культури спеціаліста й набуває якості важливого, необхідного компонента його конкретно професійної підготовки. Доведено, що фрілософрія у вищій школі має виконувати інтегрувальну функцію, а саме за допомогою фрілософрії до компетентності майбутніх фрахівців мають включатися вміння сприймати спеціальні знання з різних наук як єдине взаємопов'язане ціле. Зміст фрілософського знання є обов'язковим складником у закладі вищої освіти, що у свою чергу дозволяє включати студентів до світовоі культури й на їі базі сформувати науковий світогляд. Підкреслено, що головним результатом вивчення окремих наукових дисциплін повинно бути фрормування профресійної компетентності.
\end{abstract}

Ключові слова: професійна компетент ність, фрілософрія, профресійна підготовка, культура мислення, духовність.

The system of forming professional competence of the future specialist in higher education institutions historically provided for a detailed study of philosophy. Professional competence of the future specialist includes the ability to identify the most general laws of world development reflected in principles, laws, categories; the study of the present and the past, a possible future, which cosequently make up a scientific task of philosophy. The article deals with modern approaches to the formation of professional competencies in organizing and conducting practical classes on philosophy. Philosophy in higher education institutions is an important academic discipline that forms the integral world picture of a future specialist, implements the ability to provide the definition of processes and phenomena, develops skills to formulate, organize, consistently lay out certain position. Professional competence is characterized as a multifaceted formation and includes fundamental, subject, psychological, pedagogical and methodological competence. It is determined that the study of philosophy by students enriches their scientific worldview and helps in professional activity, ceases to be aimed only at the development of specialists' general culture and acquires the status of a significant component in their specific training. It is proved that in high school philosophy should perform an integrative function, namely: due to philosophy to future specialists' competence there should included skills to perceive special knowledge of various sciences in their interconnection. The content of philosophical knowledge is a major component in higher education institutions, which consequently allows to involve students into the world culture and to form a scientific outlook. It is emphasized that the main result of studying certain scientific disciplines should be the formation of professional competence.

Key words: professional competence, philosophy, professional training, mental culture, spirituality.
Постановка проблеми в загальному вигляді. Сучасна українська молодь живе «в добу великих та постійних змін». Відбулися зміни в політичному та економічному устрої суспільства, змінилися його духовні та ідеологічні аспекти.

Сьогодні потрібні люди 3 новим світосприйняттям. Якщо ми прагнемо інтегруватися в європейський та світовий простір, то маємо сприяти формуванню нової генерації українських інтелектуалів, з новим світоглядом та сорормованими професійними компетентностями.
Система фрормування профресійної компетентності майбутнього фрахівця в закладах вищої освіти історично передбачала детальне вивчення фрілософії. Профресійна компетентність майбутнього спеціаліста включає здатність до виявлення найбільш загальних закономірностей розвитку світу, виражених у принципах, законах, категоріях; вивчення сучасного й минулого, можливого майбутнього, що водночас і становить наукове завдання фрілософії.

Саме вивчення фрілософії допоможе молодим людям зрозуміти докорінні зміни, які відбуваються 
у світоглядних побудовах, і спричинені ними зміни в практичному ставленні людей до себе та до світу, усвідомити історичний характер людського буття, роль та значення суб'єктивних чинників на сучасному етапі.

3 одного боку, особистість має усвідомити цілісність духовного життя людства, а 3 іншого переконатися, що світ складний, різновекторний, і потрібно вміти поєднувати й узгоджувати різнопланові тенденції. Результатом мають бути фрілософське ставлення особистості до сучасного стану розвитку суспільства як до процесу, зумовленого історичними та соціальними обставинами, що невпинно змінюються; внутрішня готовність до змін; усвідомлення їхньої невідворотності; прогнозування перспектив розвитку та пошук свого місця в сучасному світі.

Аналіз останніх досліджень і публікацій. Упродовж багатьох років вчені В. Астахова, В. Лозовий, Б. Рідінгс, А. Сабірова, М. Сидоров, М. Тур займалися вивченням значення та місця фрілософрії в системі освіти.

Проаналізувавши різні погляди науковців щодо історії розвитку вищої освіти, необхідно зазначити, що процес поступового обмеження місця фрілософії в процесі професійної підготовки фрахівців свідчить про негативний вплив на якість вищої освіти та фрормування профресійної компетентності спеціалістів.

Мета статті - аналіз сучасних підходів до фрормування професійних компетентностей під час організації та проведення практичних занять із фрілософрії.

У процесі вивчення сучасних підходів до фрормування профресійних компетентностей під час організації та проведення практичних занять із фрілософрії було використано методи аналізу, узагальнення та систематизації наукових положень; синтезу, а також скласифріковано визначення профресійних компетентностей.

Виклад основного матеріалу. Тенденцією розвитку освіти в сучасному світі є впровадження в педагогічній процес компетентнісно-орієнтованої освіти, яка сприяє набуттю студентами компетентностей, необхідних в їхньому житті.

Зміст поняття «competentia» в перекладі 3 латинської мови означає сукупність питань, 3 якими людина добре обізнана, має відповідний досвід; компетентність у визначеній сорері характеризується як володіння знаннями та здібностями, які сприяють результативному здійсненню своєї діяльності в певній галузі, тобто компетентність $€$ результатом набуття компетенції [7, с. 241]

Як зазначає дослідниця Г. Єльникова, компетенція - це поняття, що стосується роботи й характеризує відповідну сореру профресійної діяльності, в якій працівник $є$ компетентним, натомість компетентність - це поняття, що стосується людини, розкриває аспекти її поведінки й забезпечує професійно якісне виконання роботи [3].

Відповідно до вищенаведених визначень необхідно зазначити, що компетенція - це задана норма, а компетентність - це сорормована властивість, результат діяльності, надбання майбутнім фрахівцем.

Інший дослідник Дж. Рейвен у своїх наукових працях описує термін «компетентність» як сукупність незалежних структурних елементів когнітивної та емоційної сорер [11].

На думку І. Зязюна, компетентність - це здібність вирішувати професійні завдання, для яких особистість має володіти відповідними знаннями, вміннями, навичками та практичним досвідом. Учений вважає, що компетентність майбутнього спеціаліста виявляється у вибраній професійній діяльності як комплексна властивість із визначеною структурою [1, с. 34].

О. Савченко зазначає, що профресійна компетентність - це готовність до виконання фраховоспрямованої діяльності та спроможність суб'єкта діяльності до реалізації повсякденних професійних завдань [8]. А дослідниця В. Лозовецька описує професійну компетентність як сорормоване вміння міркувати й оцінювати професійні ситуації та проблеми; усвідомлення розуміння особистої відповідальності за власні результати своєї діяльності [5, с. 180].

Необхідно зазначити, що фрормування професійної компетентності - це процес, що здійснюється впродовж усього профресійного становлення, основними стадіями якого є: фрормування профресійних намірів і спрямованості, профресійна підготовка, професіоналізація [7].

Таким чином, професійна компетентність майбутніх фрахівців, на наш погляд, позначає систему індивідуальних якостей, продуктивних знань, що сприяють кращій самоорганізації в професійній діяльності. Профресійна компетентність характеризується як багатоаспектне утворення і включає фундаментальну, предметну, психолого-педагогічну, методичну компетентності.

У фрормуванні професійних компетентностей у майбутніх фрахівців важливу роль відіграє вивчення фрілософрії, оскільки її головною місією $€$ оволодіння основами загальної духовної культури, насамперед культури мислення та свідомого формування системи поглядів на світ, самого себе та своє місце в сучасному світі [4].

Філософрія допомагає сформувати особистість, яка вміє думати й діяти самостійно. Вивчення фрілософрії - це входження у світ загальнолюдських цінностей, включення до вічних проблем людського існування. Основне завдання, яке реалізується на цьому етапі, - навчитися бачити проблему, чітко її усвідомлювати, розуміти й фрормулювати [9, с. 68]. 
Визначено, що фрілософрія існує для життя й має використовуватися в усіх його сорерах. Відповідно до цього для фрілософрії процес пошуку істини має важливе значення на рівні самої істини. Процес фрілософрствування характеризується пошуком істини. У цьому аспекті фрілософрія має унікальне значення. Головним предметом її вивчення є сама думка.

Формуючи свою фрілософрську позицію, людина має можливість вибирати серед багатьох позицій та поглядів. Це відкриває перед нею значні можливості для саморозвитку та самоактуалізації.

Відомо, що метою кожної людини має бути вдосконалення своєї особистості - це основний фундамент вивчення всіх фрілософрських систем, оскільки лише в результаті саморозвитку можна вдосконалити світ.

Філософрія сконцентрована на усвідомленні змістовності різних явищ та спрямована на розуміння людиною її світоглядної ролі. Відповідно до цього фрілософрію називають «любов'ю до мудрості», яка включає гносеологічний аспект $[10$, с. 68]. Ця фрункція фрілософрії ототожнюється 3 головною функцією освіти. 3 виникненням у європейських країнах системи освіти фрілософрія стала основною теоретичною дисципліною, без вивчення якої неможливо було здобути вищу освіту [4].

Отже, фрілософрія оберігає розум, їй належить роль арбітра у справах інших наук на тій основі, що тільки вона може судити автономно, самостійно, використовуючи принципи чистого мислення відповідно до законів розуму. Університет має можливість не тільки сорормувати професійність у студента, але й розвинути його світогляд.

Дослідник Дж. Г. Ньюмен у своїх наукових працях запропонував класифрікувати освіту за двома видами. Основною метою першого виду $є$ фрормування універсального, вільного знання, що веде до фрілософії, а другий вид передбачає здобуття часткового механістичного наукового знання [6, с. 105].

Основною кінцевою метою вищої освіти є фрормування у майбутніх фрахівців здатності орієнтуватися в наукових теоріях та морально-практичної компетентності під час використання отриманих знань у процесі вивчення фрілософрії.

У закладі вищої освіти фрілософрія має здійснювати інтегрувальну функцію, оскільки в процесі її вивчення майбутні спеціалісти мають бути готовими навчитися сприймати спеціальні знання окремих наук як єдине взаємопов'язане ціле. Головною метою вивчення окремих навчальних предметів має бути фрормування людини та професійної компетентності майбутнього фрахівця. 3 метою реалізації адекватного світосприйняття у майбутніх фрахівців, що виступає результатом вищої освіти, необхідно рухатися до індивідуального образу цілісного світу.
Таким чином, щоб зрозуміти предмет дослідження, його потрібно осмислити з різних позицій. У процесі вивчення фрілософрії майбутній фрахівець має навчитися зіставляти різні підходи, критично ставитись до власних і чужих оцінок, відчувати свою відповідальність за зроблений вибір.

Для того щоб майбутній фрахівець навчився фрілософрствувати, потрібно виробити в нього вміння узагальнювати, а для цього недостатньо підручника, необхідно вивчати фрілософські першоджерела. Крім того, варто акцентувати увагу на тому, що фрілософрію не можна завчити, вона потребує розуміння й вироблення власної позиції. Сьогодні фрілософрія виступає важливим складником духовної культури людства. Ставлення людини до фрілософії характеризує її загальну та профресійну культуру. Таким чином, оволодіння фрілософією $€$ ядром загальнокультурної і загальнотеоретичної гуманітарної підготовки фрахівців різного профілю.

Філософрія виконує методологічну фрункцію, яка характеризується як надання готових зразків фрорм, способів та прийомів мислення, за допомогою яких можна самостійно вирішувати наукові проблемні питання. Крім того, фрілософрія фрормує необхідні профресійні компетентності, а саме: вміння ставити питання й шукати можливі способи та методи їхнього вирішення, вивчати альтернативи та суперечності; можливість надавати визначення: більш конкретно узагальнювати зміст визначених термінів; уміння фрормулювати, поетапно здійснювати аналіз власних думок; мати своє унікальне світосприйняття, власний стиль мислення, життєві установки та ціннісні орієнтації, які є необхідними для активної роботи в різних сорерах життя [10].

Отже, фрілософія відіграє важливе значення в процесі формування професійної компетентності майбутнього фрахівця. Розвиток вищої освіти в наш час, її зміст, стратегія та конкретні методики свідчать про те, що модель сучасного університету розвивається під впливом технократичного мислення. Сучасний запит на підготовку вузьких фрахівців у процесі значної економії веде до втрати важливих традиційних фрункцій вищої освіти, і передусім культурологічної [2].

Аналізуючи програми з фрілософії, необхідно зазначити, що їхній зміст відповідає державному стандарту освіти і спрямований на вирішення завдань із формування професійних компетентностей студентів.

Так, беручи до уваги деякі теми, які вивчаються в процесі викладання фрілософрії, можна визначити, які професійні компетентності вони допомагають сорормувати в майбутніх фрахівців. Наприклад, у процесі вивчення теми «Філософрія як специфічний тип знання» у студента формується науковий світогляд та фрілософська культура мислення. Крім того, майбутні спеціалісти усвідомлюють 
сенс існування людини, виділяють ознаки добра і зла, щастя та нещастя.

Теми, що стосуються історії розвитку фрілососрської думки, ознайомлюють майбутніх фрахівців 3 культурними надбаннями людства, а також із найкращими представниками та фрілософсськими підходами. Знання про фрілософрську спадщину людства допомагають студенту навчитися самостійно мислити, фрормулювати власну позицію. Критичність до власних знань $є$ необхідною для людини, оскільки оберігає її від зарозумілості, робить її підготовленою до комунікації, дозволяє їй з повагою ставитись до інших думок [4, с. 18].

У процесі вивчення теми «Духовний вимір людського буття» студенти краще пізнають свій внутрішній світ.

Під час опанування теми «Основний зміст пізнавальної діяльності» майбутні фрахівці отримують знання про методи і способи пізнання та дослідження реальності, що надалі допомагає молодим людям пізнавати навколишній світ та вибрану профресійну діяльність.

Тема «Філософрський аналіз суспільства» інфрормує студентів про основні аспекти економічного та політичного життя суспільства, без знання яких неможливо бути сучасною людиною.

Тема «Цінності в житті людини й сучасного суспільства» вивчає важливі цінності в житті особистості та соціуму, окреслює задовільні шляхи і способи реалізації цих цінностей.

Для більш якісного фрормування професійних компетентностей студентів у процесі вивчення фрілософрії використовуються інтерактивні методи навчання, а саме: «Акваріум», «Коло ідей», «Мозковий штурм», «Займи позицію», фрронтальні опитування та методи «Мікрофрон», «Кейс-ситуації». Запропоновані інтерактивні методи дають можливість, реалізовуючи компетентнісний підхід через активну різноманітну діяльність студентів у проблемних ситуаціях, фрормувати активні соціальні вміння і практичні навички.

У процесі вивчення фрілософії майбутні фрахівці починають усвідомлювати, що абсолютних істин не може бути, кожна думка має право на існування, тому навчаються толерантно ставитися до інших, бути гуманними, але також вчаться грамотно та культурно вести дискусію, відстоювати власну позицію.

Отже, вивчення фрілософрії на практичних заняттях має для студентів важливе значення, а саме:

1. Відбувається формування культури креативного мислення особистості, якою має володіти сучасний фрахівець.

2. Культура розумового мислення відкриває для майбутнього спеціаліста шлях до творчої діяльності.

3. Знання, які отримують студенти в процесі вивчення фрілософії, фрормують у фрахівця стра- тегічне мислення, визначаючи шлях до успіху і в професійній діяльності, і в його особистому житті.

4. Отримані знання в галузі фрілософрії збільшують можливості фрахівця завдяки вільному використанню їх у своїй професійній діяльності.

Унаслідок цього він починає краще усвідомлювати та розуміти власні можливості, які закладені в нього від народження; розвивати ці здібності, збільшуючи діапазон власних професійних навичок з метою досягти ефрективного результату у профресійній діяльності та в особистому житті.

Висновки. Вища освіта сучасної України спрямована на досягнення високого рівня підготовки майбутнього фрахівця. Філософія - одна з тих наук, що покликані сприяти формуванню всебічно розвинутої особистості.

Зміст фрілософрського знання $€$ обов'язковим складником у закладі вищої освіти, що у свою чергу дозволяє включати студентів до світової культури й на її базі сорормувати науковий світогляд. У процесі викладання фрілософії науково-педагогічним працівникам необхідно донести, вкласти, продемонструвати органічну єдність фрілософрської проблематики із професійною діяльністю. Практичні заняття допомагають майбутньому фрахівцю краще зрозуміти цей зв'язок.

Таким чином, вивчення фрілософії студентами збагачує їх науковими знаннями світоглядного характеру та допомагає у професійній діяльності, перестає бути спрямованим лише на розвиток загальної культури спеціаліста й набуває якості важливого, необхідного компонента його конкретно профресійної підготовки.

Крім того, фрілософрія як системоутворювальний елемент університетської освіти $€$ неодмінною передумовою фрормування професійної компетентності майбутнього фахівця. Класична університетська модель освіти передбачає вивчення фрілософрії як провідної дисципліни, яка фрормує в майбутнього спеціаліста цілісну картину світу, вміння давати визначення, можливість формулювати, впорядковувати, послідовно викладати свої думки.

Отже, фрілософрія була й залишається інтелектуальною формою відповіді на глибинні занепокоєння та запити людини; вона завжди необхідна людині, а найчастіше тоді, коли життя потребує зробити вибір, наприклад, визначити моральну та соціальну позиції. На основі цього усвідомлення значення фрілософрії в житті людства та її поглиблене вивчення $є$ надзвичайно важливим у сучасному світі.

\section{БІБЛІОГРАФІЧНИЙ СПИСОК:}

1. Зязюн І.А. Інтелектуально-творчий розвиток особистості в умовах неперервної освіти. Неперервна профресійна освіта: проблеми, пошук, перспективи : монографрія. Київ : Вид-во «Віпол», 2000. C. 11-57. 
2. Ільїна Г.В. Ґенеза культури мислення: логос, раціо, візіо : монографрія. Київ ; Ніжин : Видавець ПП Лисенко М.М., 2018. 368 с.

3. Єльникова Г.В. Теоретичні і методичні засади моделювання фрахової компетентності керівників закладів освіти : монографрія. Київ ; Чернівці : КнигиXXI, 2010. 460 c.

4. Кириленко К.М. Філософрія культури. Київ, 2018. 279 c.

5. Лозовецька В.Т. Професійна компетентність. Енциклопедія освіти. Київ : Юрінком Інтер, 2008. C. 180 .

6. Ньюмен Дж.Г. Идея университета. Минск : БГУ, 2006. $208 \mathrm{c}$.

7. Рудніцька К.В. Сутність понять «компетентнісний підхід», «компетентність», «компетенція», «професійна компетентність» у світлі сучасної освітньої парадигми. Науковий вісник Ужгородського універ- ситету. «Педагогіка. Соціальна робота». 2016. Вип. 1 (38). С. 241-243.

8. Савченко О.П. Компетентнісний підхід у сучасній вищій школі. Педагогічна наука: історія, теорія, практика, тенденції розвитку. 2010. № 3. URL: http://intellect-invest.org.ua/pedagog_editions emagazine_pedagogical_science_vypuski_n3_2010_ st_16 (дата завернення: 15.04.2021).

9. Тур М.Г. Роль і місце фрілософрії в освіті та науці. Вісник гуманітарного наукового товариства : Наукові праці. Черкаси, 2014. Вип. 14. С. 68-77.

10. Філософрія освіти: навчальний посібник / за наук. ред. академіка В.П. Андрущенка та ін. Київ : Вид-во НПУ імені М.П. Драгоманова, 2018. $342 \mathrm{c}$.

11. John Raven, H. K. Lewis \& Co. Competence in modern societ - its identification, development and release. s.I. London, 1984. 